\title{
EFFECT OF EPINEPHRINE ON IMPLANTATION AND FOETAL SURVIVAL IN THE RABBIT
}

\author{
F. J. AULETTA \\ Department of Obstetrics and Gynecology, \\ Tale University School of Medicine, \\ New Haven, Connecticut 06510, U.S.A.
}

(Received 2nd Fune 1971)

Observations in recent years have shown that the catecholamines may play an important rôle in reproductive physiology, though there is a lack of data on the effects of these compounds in early pregnancy. Epinephrine has been shown to influence ovum transport and the motility of the rabbit oviduct (Longley, Black \& Currie, 1968a, b). Recently, Crist \& Hulka (1970) have shown that subcutaneous injections of epinephrine impair implantation in rats when given on Days 1 to 6 after mating, but have no effect on embryo survival when administered after implantation has occurred. The purpose of the present study was to determine the effect of epinephrine on ovum implantation and foetal survival in the rabbit.

Virgin female Dutch-Belted rabbits were mated to fertile bucks and injected with 100 i.u. HCG (Ayerst Laboratories, New York) to ensure ovulation. The day of mating was termed Day 0 . All animals were examined by laparotomy under Diabutal anaesthesia on Day 10 and the numbers of corpora lutea and implantation sites were recorded; the animals were killed on Day 28 and the numbers of normal, arrested and abnormal foetuses were recorded. Control animals were injected subcutaneously with $1 \mathrm{ml}$ normal saline twice daily on Days 3 to 6,6 to 7 and 7 to 9 . The treated groups received $600 \mu \mathrm{g} / \mathrm{kg}$ of epinephrine subcutaneously twice daily on Days 3 to 5,6 to 7 and 7 to 9. Data were analysed by the Student's $t$ test (Steel \& Torrie, 1960).

The results of this study are presented in Table 1 . Normal saline did not affect ovum implantation or foetal survival in the rabbit. Animals injected with epinephrine on Days 6 to 7 and 7 to 9 had a decreased number of implantations when compared to saline groups on the same day $(P<0.01$ and $P<0.05$, respectively). All epinephrine-treated animals had a significantly lower number of normal foetuses $(P<0.01)$ than the control animals. There was also an increased incidence of arrested foetuses in the epinephrine study. Within the treatment group, injections of epinephrine on Days 6 to 7 caused a highly significant decrease in the number of implantation sites compared with the animals injected on Days 3 to 5 and 7 to 9 . The number of normal foetuses in the Day- 6 to 7 and 7 to 9 experiments was greatly reduced when contrasted to the Day-3 to 5 animals $(P<0.01)$. There were no normal foetuses in the animals injected on Days 7 to 9 . Gastroschisis was observed in one foetus from the Day6 to 7 epinephrine injection group which was examined on Day 28. 
TABLE 1

EFFECT OF EPINEPHRINE ON EARLY PREGNANGY IN THE RABBIT

\begin{tabular}{|c|c|c|c|c|c|c|}
\hline \multicolumn{2}{|c|}{$\begin{array}{l}\text { Treatment and } \\
\text { Day of gestation No. of rabbits }\end{array}$} & $\underset{\text { Norpora of lutea }}{D}$ & $\begin{array}{l}10 \\
\text { No. and } \% \text { of } \\
\text { implantations }\end{array}$ & $\begin{array}{c}\text { No. and } \% \\
\text { of normal } \\
\text { foetuses }\end{array}$ & $\begin{array}{l}28 \text { foetuses } \\
\text { Arrested } \\
\text { foetuses }\end{array}$ & $\begin{array}{l}\text { Abnormal } \\
\text { foetuses }\end{array}$ \\
\hline $\begin{array}{c}\text { Saline controls } \\
\text { Days } 3 \text { to } 6 \\
\text { Days } 6 \text { to } 7 \\
\text { Days } 7 \text { to } 9\end{array}$ & $\begin{array}{l}4 \\
3 \\
3\end{array}$ & $\begin{array}{l}30 \\
20 \\
22\end{array}$ & $\begin{array}{l}26(86.7 \%) \\
19(95.0 \%) \\
18(81.8 \%)\end{array}$ & $\begin{array}{l}24(80 \cdot 0 \%) \\
17(85.0 \%) \\
16(72 \cdot 7 \%)\end{array}$ & $\begin{array}{l}2 \\
0 \\
0\end{array}$ & $\begin{array}{l}0 \\
0 \\
0\end{array}$ \\
\hline Total & 10 & 72 & $63(87.5 \%)$ & $57(79.1 \%)$ & 2 & 0 \\
\hline $\begin{array}{l}\text { Epinephrine } \\
\text { Days } 3 \text { to } 5 \\
\text { Days } 6 \text { to } 7 \\
\text { Days } 7 \text { to } 9\end{array}$ & $\begin{array}{l}3 \\
9 \\
4\end{array}$ & $\begin{array}{l}20 \\
69 \\
29\end{array}$ & $\begin{array}{l}17(85 \cdot 0 \%) \\
23(33 \cdot 3 \%)^{*} \\
20(70 \cdot 0 \%)\end{array}$ & $\begin{array}{r}11(55.0 \%) \\
8(11.6 \%) \\
0\end{array}$ & $\begin{array}{l}3 \\
3 \\
5\end{array}$ & $\begin{array}{l}0 \\
1 \uparrow \\
0\end{array}$ \\
\hline Total & 16 & 118 & $60(50 \cdot 8 \%)$ & $19(16.1 \%)$ & 11 & 1 \\
\hline
\end{tabular}

* Eleven out of twenty-three implantation sites were small.

$\dagger$ One foetus had gastroschisis.

The mechanism of action of epinephrine in interfering with ovum implantation and foetal survival is not clear. A possible mechanism is foeto-placental anoxia due to vasoconstriction of the uterine vessels. In the light of the recent work of Yang, Yang \& Lin (1969) and Chatterjee \& Harper (1970), which indicates that increased amounts of adrenal corticosteroids interrupt pregnancy in the rat, it is conceivable that epinephrine, acting through the hypothalamopituitary axis, releases ACTH which in turn causes the release of excessive quantities of corticosteroids. In support of this hypothesis, epinephrine has been shown to increase ACTH secretion with a resulting increase in adrenal steroids (Long, 1952).

Epinephrine interferes with ovum implantation and foetal survival in the rabbit. The time sequence of the injections is critical and a pharmacological dose of epinephrine is essential for the effect. There also exists a possible teratogenic action as illustrated by the foetus with gastroschisis.

The author is indebted to Professor John McLean Morris for his criticism of the manuscript. This work was supported by a grant from the Ford Foundation

\section{REFERENCES}

Chatterjee, A. \& Harper, M. J. K. (1970) Interruption of implantation and gestation in rats by reserpine, chlorpromazine and ACTH: possible mode of action. Endocrinology, 87, 966.

CRIST, T. \& HUL.KA, J. F. (1970) Influence of maternal epinephrine on behaviour of offspring. Am. 7 . Obstet. Gynec. 106, 687.

LoNG, C. N. H. (1952) Regulation of AcrH secretion. Recent Prog. Horm. Res. 7, 75.

Longley, W. J., BlAck, D. L. \& CuRRIE, G. N. (1968a) Oviduct circular muscle response to drugs related to the autonomic nervous system. F. Reprod. Fert. 17, 95.

LONGLEY, W. J., BLACK, D. L. \& CuRRE, G. N. (1968b) Ovarian hormone control of ovum transport in the rabbit as influenced by autonomic drugs. F. Reprod. Fert. 17, 579.

Steel, R. G. D. \& ToRrIe, J. H. (1960) Principles and procedures of statistics. McGraw-Hill, New York.

YANG, W. H., YANG, W. P. \& LIN, L. L. (1969) Interruption of pregnancy in the rat by administration of ACTH. Endocrinology, 84, 1282. 